\title{
Death and the Herb Thyme
}

\section{S. O. Addy}

To cite this article: S. O. Addy (1903) Death and the Herb Thyme, Folklore, 14:2, 179-180, DOI: 10.1080/0015587X.1903.9719354

To link to this article: http://dx.doi.org/10.1080/0015587X.1903.9719354

$$
\text { 曲 Published online: } 06 \text { Feb } 2012 .
$$

5 Submit your article to this journal $₫$

Џll Article views: 1

Q View related articles ¿ 
Mr. Sweetland said his father talked of the old war, and the soldiers marching after the battle to King's Down.

The Squire of Warleigh Manor showed me two cannon-balls found in Claverton Manor. The villagers told me these little stories as if it had all happened a few years ago.

Ottober, 1902.

KATE LEE.

[These traditions probably refer to the skirmish of 3 rd July, I643. The Parliamentary forces under Waller held Bath, and were attacked by the Royalists under Hopton, who had marched from Chewton, north of the Mendips, eastwards to Frome, and then northwards by the valley of the Avon, on their way to join the king. On the 3 rd July they "drew a small body of the enemy out of Monkton Farleigh, on the high ground to the north of the river, but Waller's main army was on the other side of the valley, under Claverton Down, and they neither dared to cross the river in the face of the enemy, nor to pursue their way to Bath, leaving him in the rear." They therefore pushed on through Monkton Farleigh and worked round to the north-west of Bath, where the indecisive battle of Lansdown was fought on July $5^{\text {th. }}$ (Gardiner's History of the Civil War, i., I98.) It does not appear that the King was present. Collinson's History of Somerset ( 1791 ) says of Claverton: "The manor-house is a noble old building adjoining to the Church. . ... In the Civil Wars temp. Car. I., when Sir William Basset, Sir Edward Hungerford, and other gentlemen, were dining in this house, a cannon ball, directed from the hill opposite, pierced through the outer wall of the hall, and passing over the table at which they sat, lodged in the breast wall of the chimney without doing further mischief," (vol. i., p. 146),-..-Es.]

Death and the Herb Thyme.

In William Thornber's History of Blackpool, ${ }^{8} 837$, p. 38 , it is said that the "boggart" of Staining Hall, near the town, was "the wandering ghost of a Scotchman, murdered near a tree, which has since recorded the deed by perfuming the ground around with 
a sweet odour of thyme." I have mentioned a sinilar belief in my" Household Tales and Traditional Remains, p. 63, where it is related that "a smell of thyme may always be perceived near a footpath leading from Dronfield to Stubley, in Nerbyshire. It is said that a young man murdered his sweetheart there as she was carrying a bunch of thyme." About two years ago Mrs. George Middleton, of Smalldale, near Bradwell, in Derbyshire, told me that her mother, who lived at Abney in that county, used to dress coffins with flowers. But she would never put thyme on a coffin, for she said that a dead man had "nothing to do with time." Mrs. Middleton further said that her mother was present at all births and laying out of corpses at Abney, not as a part of her duty, but because she liked to be present. It was, however, the custom at $A$ bney to put thyme in a house both before and after a funeral, and also southernwood, otherwise "old man" or "lad's love."

The Oddfellows of Bradwell bave a custom which is the exact opposite of the Abney woman's refusal to lay thyme on a coffin. When one of their members dies, the survivors accompany his body to the grave, and ench of them carries a sprig of thyme in his hand, which he drops on the coffin.

Scattered all over the moors about Abney and Bradwell are the "lows" or tombs of the ancient dead, and there the wild thyme grows abundantly.

S. O. ADDY. 